\title{
Framework Model in Implementation of Spatial Policy in Makassar City (Framework Model in Implementation of Spatial Policy Change of Makassar City)
}

\author{
Aslinda. ${ }^{1} \&$ Muh. Akmal Ibrahim ${ }^{2}$ \\ ${ }^{1}$ Department of Fisheries Agribusiness, Agricultural Polytechnic State Pangkep, South Sulawesi, Indonesia \\ ${ }^{2}$ Department of Administration, Faculty of Social and Political Sciences, Hasanuddin University, South Sulawesi, \\ Indonesia \\ Correspondence: Aslinda., Department of Fisheries Agribusiness, Agricultural Polytechnic State Pangkep, South \\ Sulawesi, Indonesia. E-mail: aslinda110@yahoo.com
}

\author{
Received: May 11, 2014 Accepted: July 26, 2014 Online Published: August 15, 2014 \\ doi:10.5539/ass.v10n18p37 \\ URL: http://dx.doi.org/10.5539/ass.v10n18p37
}

\begin{abstract}
The study aims to analyze and explain regional spatial policy change by applying policy subsystem variables based on ACF version 1998 by Sabatier and Jenkins-Smith. Policy subsystem variables consisting of policy core beliefs, advocacy coalition, and advocacy coalition resource are assumed having influence on spatial policy change. Qualitative approach through case study strategy is applied to investigate policy change and policy subsystem in natural context. Case of the study is changes upon spatial utilization in midtown area of Makassar City. Multi-stakeholder analysis tool by GTZ (2007) is applied to obtain and analyze the data. The study concludes that policy core beliefs change comes from advocacy coalition, while advocacy coalition resource does not affect spatial policy change of Makassar City. The finding implicates theoretically that ACF model version 1998 by Sabatier and Jenkins-Smith is inapplicable to explain spatial policy change in Makassar City.
\end{abstract}

Keywords: policy change, advocacy coalition, policy core beliefs, political resource

\section{Introduction}

Spatial problem complexity in many developing countries, along with public demand on the solutions, gives strong motives for role of the government to adopt and implement spatial policy effectively. Spatial policy defines action choices performed by the government to figure out spatial problems.

Objectives of spatial policy in developing countries are varying. However, reducing poverty, rising economic growth, assuring environmental continuity, and controlling urban development belong to relevant elements of spatial policy in many developing countries (Enemark, 2012; Enemark, 2013).

Spatial policy in many developing countries meets important changes over the last decades. Policy change either in major or minor level occurs in a policy subsystem or government program. Major change refers to the changes in aspects of deep core beliefs and policy core beliefs, while minor change refers to the changes in aspects of secondary beliefs from the government policy or government program (Sabatier \& Jenkins-Smith, 1993, 1999, 2007; Sabatier \& Weible, 2005).

Deep core beliefs cover a very normative and ontological general assumption on human characteristic and fundamental values which are relatively priority, such as freedom and equivalence, role of the government vs. market, and who shall participate in government decision. Policy core beliefs cover priority to values concerning policy, prosperity, and relative authority from the government and market sector, and causes of multiple policy problems. Secondary beliefs regard regulations and budget application in a specific program, basic guidelines of public participation in a specific regulation, etc. (Sabatier \& Jenkins-Smith, 1993, 1999, \& 2007; Weible \& Sabatier, 2007; Sabatier \& Weible, 2005).

Major changes are seen in spatial reconfiguration from economic perspective, and also role of the government regulation in framing spatial outcomes. Minor changes are seen in institutional change of space management and program re-priority and financial resource allocation.

Spatial policy change, as elucidated above, also occurs over the last five years in Makassar City, South Sulawesi, 
Indonesia. Spatial policy of Makassar City is outlined in Regional Regulations No. 6 of 2006 on Regional Spatial Management of 2005-2015. Complying with the regulation, all spaces in Makassar City are divided into five Development Regions (Wilayah Pengembangan or WP) and 13 Integrated Development Region (Kawasan Pengembangan Terpadu or KPT).

Spatial policy change at macro level is indicated by role of the local government regulation in executing space reconfiguration in midtown area and integrated settlement in WP I to turn it business looks through Losari Beach reclamation for hotel construction and Karebosi soccer field revitalization. Current local government of Makassar City argues that business oriented policy is the right instrument to boost infrastructure development and regional economic growth in order to realize the vision of being Metropolis.

Spatial reconfiguration to the more business oriented region in Makassar City for 2007-2012 has made impressive financial output. Local economy is evaluated by gross regional domestic product which shall grow above 9 percent in average, so it can place Makassar City as a city with the highest growth rate among cities in Indonesia. However, impressive growth rate has not been significantly tailed by capability to reduce poverty. Poverty rate in Makassar City of 2012 based on per capita income standard with total income less than USD 1 per day is $5.1 \%$. This rate is just 0.25 point different from previous rate in 2007 (The World Bank, 2012) meaning that during period of 2007-2012, poverty rate decreases 0.05 percent per year only.

One of applied theories in the study to analyze and explain spatial policy change of Makassar City is Advocacy Coalition Framework (ACF) version 1998 by Sabatier and his colleagues. ACF is proposed by Sabatier and his colleagues in late 1980s to explain political behavior of the actors in policy process (Sabatier and Jenkins-Smith, 1988). To the present time, ACF has met each of minor revision and major revision twice. Minor revision is conducted in 1993 and 2005, while major revision occurs in 1998 by Sabatier and Jenkins-Smith and in 2007 by Sabatier and Weible (Weible et al., 2009).

In order to explain policy change process, ACF version 1998 specifies policy subsystem as the main analysis unit. ACF identifies policy beliefs and advocacy coalition resource as causal driver of advocacy coalition's behavior in policy subsystem (Weible et al., 2009). ACF version 1998 by Sabatier and colleagues clarify that policy change mainly occurs as the consequence of competition among advocacy coalitions in policy subsystem. Based on striven policy beliefs, advocacy coalition in policy subsystem is divided into major coalition and minority coalition. Major coalition is the determinant of policy processes, while minority coalition tries to affect government policy and to defend its relative position (Sabatier \& Jenkins-Smith, 1999; Weible \& Sabatier, 2007).

A number of empirical studies have been conducted to various policy domains and in many countries to verify theoretical propositions of ACF. Over more than two decades, ACF has been applied in Europe, Canada, US, and other developing countries including Indonesia to a large number of important topics, such as policies on health, environment, forestry, economy, disturbance, and education (Weible, Sabatier, \& McQueen, 2009). However, the findings of empirical analysis on policy change plot and affecting factors are still inconsistent.

Ainuson (2009) applies ACF approach to explain water policy change in Ghana; Meijerink (2005) applies ACF model to explain flood control policy change in coastal areas in the Netherlands; Kübler (2001) applies ACF model to explain medical policy change in Swiss. All findings of those studies support ACF hypothesis on policy changes, that there is competition among advocacy coalitions belief system concerning policy problems, and the competition encourages new objectives image.

Previous studies applying ACF model do not collaborate on how policy core beliefs and advocacy coalition resources detailed at secondary level.

ACF model version 1998 by Sabatier and colleagues identifies policy core beliefs and advocacy coalition resource as causal driver in policy subsystem delivering policy change. All findings of empirical analysis by Ainuson (2009), Suwitri (2008), Meijerink (2005), Kübler (2001) and Litfin (2000) support the ACF prediction. The study assumes that policy core beliefs and advocacy coalition's resource may explain the process of spatial policy change.

\section{Research Method}

The study applies qualitative approach. Data in use is collected from the chosen participant, program document, and field observation. Multi-Stakeholder Analysis (MSA) procedure is applied to pick participant, to collect data and to direct data analysis. Multi-Stakeholder Analysis (MSA) by GTZ (2007) applied in the study is identification of key stakeholder, stakeholder mapping, and stakeholder authority and resource. Field notes, voice recorder and photo/video recorder are used to document the data. 
The study is located in WP I of Makassar City. Appointing reason to WP I as research site is that the location meets specification of ACF concept by Sabatier and Jenkins-Smith. Policy change in the WP I is indicated by reclamation activity of Losari Beach, construction of Swiss Bel-inn hotel, revitalization of Karebosi field where all of them are deviated from policy blue print.

\section{Findings and Discussion}

\subsection{Policy Core Beliefs and Its Influence on Policy Change}

Actors filling in major advocacy coalition in regional spatial policy in Makassar City are Mayor, local and central politicians (who shall not be named), business player (Hasan Basri who stands on top); while minor advocacy coalition are filled in by Governor of South Sulawesi, rent seeker politician either who stands in the same or other party. It is in line with what had been predicted in ACF model that every policy subsystem contains a large number of actors from diverse public and private organizations who show interest in policy issues (Sabatier \& Jenkins-Smith, 1993).

Major advocacy coalition and minor coalition continually compete to put their policy core beliefs into regional spatial utilization program. Major coalition promotes infrastructure growth and regional economic growth by maximizing license of spatial utilization for business interest. These license decisions, at the observed case, are deviated from policy blue print and also do not comply with regulation to higher hierarchy. Minor coalition attempts to realize public rights and social learning process in planning and budgeting.

Competition between major and minor advocacy coalition to realize policy core beliefs does not emerge new programs as compromise decision. On the contrary, competition between both advocacy coalitions turns to be political conflict. It is similar to ACF model prediction (Weible \& Sabatier, 2007) that competition among advocacy coalitions in form of political conflict in Makassar City leads to dead policy, such as stoppage upon beach reclamation and construction of Swiss Bel-inn hotel in Losari Beach. That condition is different from theoretical prediction of ACF (Weible \& Sabatier, 2007) that competition among advocacy coalitions leads to new programs which are adopted to be the government authoritative decisions. There was no new program up to 2012 as solution of the dead policy.

The findings show that there is not enough empirical evidence to back up ACF theoretical prediction by Sabatier and Jenkins-Smith version 1998. It declares that competition among advocacy coalitions create new programs. It indicates that ACF theoretical prediction by Sabatier and Jenkins-Smith on policy core beliefs as cause driver of policy change is unable to be applied to explain spatial policy change in Makassar City.

\subsection{Resource and Its Influence on Policy Change}

Resources possessed and used by major coalition in spatial policy in Makassar City are: votes and other forms of political support; money, information and skill, moral support, and position. Minor coalition only utilizes resources such as votes, position, and moral confidence. Major coalition has and utilizes more resource types than the minor one.

All resource types of advocacy coalition in spatial policy of Makassar City are political resources just as identified by Piven and Cloward (2005). Political resource utilization in regional spatial management policy complies with ACF concept that actor coalitions utilize political resource to fight for their policy core beliefs or in attempt to fix their relative position (Sabatier \& Jenkins-Smith, 1999, 1993; Weible \& Sabatier, 2007).

Political resource types are utilized in different quantity and different case either by major or minor coalition. For Karebosi field revitalization case, minor coalition uses resource combination consisting of votes, position, and moral/religious support. However, that resource combination is unable to stop the policy implementation. Operation of Karebosi field revitalization keeps running and fully finished, even it operates as planned. Else, beach reclamation and construction of Swiss Bel-inn hotel in Losari Beach may boycotted by same resource type.

The finding on advocacy coalition resource in Makassar City does not reserve empirical support to ACF theoretical prediction. It predicts that every advocacy coalition tries to realize their policy objectives by increasing political resource. Minor coalition may strive to fix its relative position by adding their resources (Sabatier \& Jenkins-Smith, 1993). It indicates that ACF theoretical prediction by Sabatier and Jenkins-Smith on advocacy coalition resource as cause driver of policy change is inapplicable to explain spatial policy change in Makassar City.

What occurs in Makassar is that in case of beach reclamation and construction of Swiss Bel-inn hotel in Losari Beach, major coalition does not attempt to systematically increase political resource in order to realize their 
policy objectives. Otherwise, in case of Karebosi field revitalization, both coalitions attempt to increase their political resources, so their competition shapes political conflict.

Advocacy coalition's effort in spatial policy in Makassar City to increase political resource is more accurate if it is explained by using rational perspective. Beach reclamation/construction of Swiss Bel-inn hotel in Losari Beach only covers private interest in small quantity. Otherwise, Karebosi field revitalization covers government sector interest, i.e. local government of Makassar City. Minor coalition stands on boycott party opposing the policy and they do not urge the making of desired institutional regulation. It indicates that major and minor coalition attempt to increase political resource just in case of competition upon public interest.

\section{Research Implication}

Practically, the study verifies key issues and policies that form regional spatial management. The findings may be utilized as material or information to re-design the more effective spatial policy structure to make it more useful for all of social purposes in Makassar City. So does the government of other region who may apply the findings for similar purpose.

\section{Conclusion}

Spatial policy change in Makassar City takes place in policy core beliefs level. Major or minor advocacy coalition has prioritized new values which are different from spatial policy blue print. Policy core beliefs change is not followed by changes in secondary beliefs level. It is indicated by the absence of spatial programs working on weak traditional institution, so it leads to anxiety and tightness.

Policy core beliefs by major coalition are maximization of space value to encourage infrastructure growth and regional economic growth. Policy core beliefs by minor coalition are optimization of regional space to create the real social prosperity. Competition between major and minor advocacy coalition to realize policy core beliefs does not emerge new programs as their compromise decision, conversely, it turns to political conflict that lead to a dead policy.

Major coalition utilizes more resource types than the minor one. Both advocacy coalitions utilize different resource at different context. Similarity of both appears that each of coalition attempts to increase political resource just in case of competition upon public interest. Competition upon private interest is not tailed by an effort to increase political resource. As the consequence, continual dead policy only occurs in private interest sector.

The findings concerning either policy core beliefs change or advocacy coalition resource do not comply with ACF theoretical prediction version 1998 by Sabatier and Jenkins-Smith. Policy core beliefs change and advocacy coalition resource do not encourage the making of new policy. All spatial policy programs are broken by major coalition. Minor coalition contest just reaches policy boycott level without encouraging the making of new program and new policy. The findings implicate theoretically that ACF model by Sabatier and Jenkins-Smith is inapplicable to explain spatial policy change in Makassar City. As the consequence, it needs qualitative study to investigate factors which may explain spatial policy change in Makassar City.

\section{References}

Ainuson, K. (2009). An Advocacy Coalition Approach to Water Policy Change in Ghana: A Look at Belief Systems and Policy Oriented Learning. Journal of African Studies and Development, 1(2), 16-27.

Bailey, N., Gannon, M., Kearns, A., Livingston, M., Leyland, \& Alastair H. (2012). Living Apart, Losing Sympathy: How Attitudes to Redistribution and to Welfare Recipients Depend on Where You Live. Paper presented at The Social Policy Association/East Asia Social Policy Research Network Conference, 16-18. New York.

Baja, S., Mustafa, M., \& Arief, S. (2011). Spatial Dynamics of Land Use/Land Cover in South Sulawesi, Indonesia. Paper presented at The Asia Geospatial Forum Conference. Jakarta.

Bevir, M. (2007). Encyclopedia of Governance. California: Sage Publications, Inc.

Cazacova, L., Erdelhun, A., Saymanlier, A. M., Cazacova, N., \& Ulbar, U. (2010). Social and Spatial Aspects of Housing Development Affecting Urban Quality of Life: The Case of Famagusta. World Academy of Science, Engineering and Technology, 4.

Enemark, S. (2012). Sustainable Land Governance: Three Key Demands. FIG Working Week 2012 Knowing to Manage the Territory, Protect the Environment, Evaluate the Cultural Heritage. Rome, Italy. 
Enemark, S. (2013). Building Fit-for-Purpose Spatial Frameworks for Sustainable Land Governance in Sub-Sahara Africa. FIG Working Week 2013Environment for Sustainability. Abuja, Nigeria.

Gould, D. G. (2002). The Evolution of Land Tenure in Forestry Management in the Philippines. Retrieved March 25, 2014, from http://www.spatial.maine.edu/.../Landtenure/.../

GTZ (Deutsche Gesellschaft für Technische Zusammenarbeit). (2007). Multi-stakeholder management: Tools for Stakeholder Analysis: 10 Building Blocks for Designing Participatory Systems of Cooperation. Eschborn, Germany: GTZ. Retrieved January 12, 2013, from http://www.gtz.de/participation

Kanbur, R., \& Venables, A. J. (2005). Spatial Inequality and Development Overview of UNU-WIDER Project. Retrieved March 25, 2014, from http://www.arts.cornell.edu/.../WIDERProjectO

Kmonwatananisa, N. (2008). Thailand's Management of Regional and Spatial Development. Paper prepared for the Senior Policy Seminar on "Management of Regional and Spatial Development". Seoul, the Republic of Korea.

Kübler, D. (2001). Understanding Policy Change with the Advocacy Coalition Framework: An Application to Swiss Drug Policy. Journal of European Public Policy, 8(4), 623-641. http://dx.doi.org/10.1080/13501760 110064429

Levitsky, S., \& Murillo, M. V. (2009). Variation in Institutional Strength. The Annual Review of Political Science, 12, 115-133. http://dx.doi.org/10.1146/annurev.polisci.11.091106.121756

Litfin, K. T. (2000). Advocacy Coalitions along the Domestic-Foreign Frontier: Globalization and Canadian Climate Change Policy. Policy Studies Journal, 28(1), 236-252. http://dx.doi.org/10.1111/j.1541-0072.2000. tb02026.x

Meijerink, S., \& Huitema, D. (2010). Policy Entrepreneurs and Change Strategies: Lessons from Sixteen Case Studies of Water Transitions around the Globe. Ecology and Society, 15(2), 21. Retrieved from http://www. ecologyandsociety.org/vol15/iss2/art21/

Owusu, J. H. (2001). Spatial Integration, Adjustment, and Structural Transformation in Sub-Saharan Africa: Some Linkage Patern Changes in Ghana. The Professional Geographer, 53(2), 230-247. http://dx.doi.org /10.1080/00330124.2001.9628454

Peraturan Daerah Kota Makassar Nomor 6 Tahun 2006 Tentang Rencana Tata Ruang Wilayah Kota Makassar 2005-2015.

Peraturan Presiden Nomor 55 Tahun 2011 tentang Rencana Tata Ruang Kawasan Perkotaan Mamminasata.

Piven, F. F., \& Cloward, R. A. (2005). Rule Making, Rule Breaking and Power. In T. Janoski, R. Alford, A. Hicks, \& M. A. Schwartz (Eds.), Handbook of Political Sociology: States, Civil Societies, and Globalization (pp. 33-53). Cambridge: Cambridge University Press.

Qing, C., Shuangcheng, L., Yanglin, W., Jiangsheng, W., \& Miaomiao, X. (2012). Spatial Process of Green Infrastructure Changes Associated with rapid Urbanization in Shenzhen, China. Chinese Geographical Science.

Ritzer, G. (2005). Encyclopedia of Social Theory. California: Sage Publications, Inc.

Sabatier, P. A., \& Christopher, M. W. (2005). Innovations in the Advocacy Coalition Framework. Paper presented at the annual meeting of the American Society for Public Administration. Milwaukee, WI.

Sabatier, P. A., \& Jenkins-Smith, H. (1988). An Advocacy Coalition Model of Policy Change and the Role of Policy Orientated Learning Therein. Policy Sciences, 21, 129-168. http://dx.doi.org/10.1007/BF00136406

Sabatier, P. A., \& Jenkins-Smith, H. (1993). Policy Change and Learning: An Advocacy Coalition Approach. Boulder, Colo.: Westview Press.

Sabatier, P. A., \& Jenkins-Smith, H. (1999). The Advocacy Coalition Framework: An Assessment. In P. A. Sabatier (Ed.), Theories of the Policy Process (pp. 117-168). Boulder, CO: Westview Press.

Sabatier, P. A., \& Jenkins-Smith, H. (2007). The Advocacy Coalition Framework: Innovations and Clarifications. In P. A. Sabatier (Ed.), Theories of the Policy Process (2nd ed., pp. 189-221). Sabatier. Boulder, CO: Westview Press.

Sotirov, M., \& Memmler, M. (2010). The Advocacy Coalition Framework in Natural Resource Policy Studies: Recent Experiences and Further Prospects. Artikel. Retrieved July 7, 2013, from http://foper.sfb.rs/pdf/ ACF_October_2010.pdf 
Sundstrom, R. R. (2003). Race and Place: Social Space in the Production of Human Kinds. Philosophy \& Geography, 6(1). http://dx.doi.org/10.1080/1090377032000063333

Suwitri, S. (2008). Jejaring Kebijakan dalam Perumusan Kebijakan Publik: Suatu Kajian Tentang Perumusan Kebijakan Penanggulangan Banjir dan Rob Pemerintah Kota Semarang. Jurnal Ilmu Administrasi, VI(3).

The World Bank. (2012). Analisis Keuangan Publik Provinsi Sulawesi Selatan 2012. Meningkatkan kualitas Pelayanan Publik dan Pengelolaan Keuangan Daerah di Gerbang Indonesia Timur. Jakarta: Kantor Bank Dunia Jakarta.

Trkulja, S. (tanpa tahun). Happiness as Indicator and Planning Objective for the Spatial Development Policy. Serbia: Faculty of Geography, University of Belgrade.

Undang-Undang Republik Indonesia Nomor 24 tahun 1992 tentang Penataan Ruang.

Undang-Undang Republik Indonesia Nomor 26 Tahun 2007 tentang Penataan Ruang.

UNECE (The United Nations Economic Commission for Europe). (2008). Spatial Planning: Key Instrument for Development and Effective Governance with Special Reference to Countries in Transition. Geneva: United Nations.

Weible, C. M., \& Sabatier, P. A. (2007). A Guide to the Advocacy Coalition Framework. In F. Fischer, G. J. Miller, \& M. S. Sidney (Eds.), Handbook of Public Policy Analysis: Theory, Politics, and Methods (pp. 123-136). Boca Raton: Taylor \& Francis Group, LLC.

Weible, C. M., Sabatier, P. A., \& McQueen, K. (2009). Themes and Variations: Taking Stock of the Advocacy Coalition Framework. The Policy Studies Journal, 37(1), 121-140. http://dx.doi.org/10.1111/j.1541-0072. 2008.00299.x

\section{Copyrights}

Copyright for this article is retained by the author(s), with first publication rights granted to the journal.

This is an open-access article distributed under the terms and conditions of the Creative Commons Attribution license (http://creativecommons.org/licenses/by/3.0/). 